\title{
A Novel Portable Device Used to Perform Autologous Blood Salvage in an Unsterilized Environment
}

\author{
Tarana Parvez Kaovasia, Siddharth Dash \\ SRM Institute of Science and Technology \\ Kattankulathur, Chennai, India \\ taranakaovasia_pa@srmuniv.edu.in; siddharthdash_sub@srmuniv.edu.in
}

\begin{abstract}
Intraoperative blood salvage (cell salvage) has been increasingly used in the past few decades; it gained attention when Jehovah's victims in 1945 introduced a doctrine not accepting allogenic blood transfusions. This created the need for autologous blood transfusion, which has gained momentum in the past few decades. However, autologous blood transfusion cannot be carried out in an unsterilized environment. A device has been proposed in this paper, which can purify upto 2 liters of blood lost by an individual, and transfuse it back into the body. The unique feature of this device is that it works in an unsterilized environment. The time taken for the device to start transfusing the purified blood back is 60 seconds and the process continues until the entire volume of blood lost is recuperated. The device was built keeping in mind the numerous lives that are lost in wars and natural disasters to bring about immediate relief to those affected.
\end{abstract}

Keywords: Autologous, Unsterilized, Portable, Intravenous.

\section{Introduction}

Autologous blood transfusion is a method used to recover blood that is lost by a person and retransfuse it back into the body [1]. This method has been gaining popularity in surgical procedures, especially those involving substantial blood losses (Loss of $20 \%$ of blood volume is potentially life threatening) [2]. It reduces the burden on the immune system and is particularly useful for individuals with rare blood types. The major challenge faced by autologous blood transfusion is that it requires a sterilized environment to carry out the procedure. The reason being, in an unsterilized environment the blood becomes susceptible to a number of foreign particles, including dust, dirt and pathogens like bacteria, fungi and viruses. The blood once infected, cannot be infused back into the body without cleaning it. The proposed device salvages the already lost blood, cleans it and transfuses it back into the body. The foreign particles are removed in a sequential manner as the blood passes through the device. This is achieved by compartmentalizing the device into many segments. Fig. 1 provides a schematic diagram depicting the basic layout of the proposed device. The general and segment specific functions of the device are discussed throughout the length of this paper. 


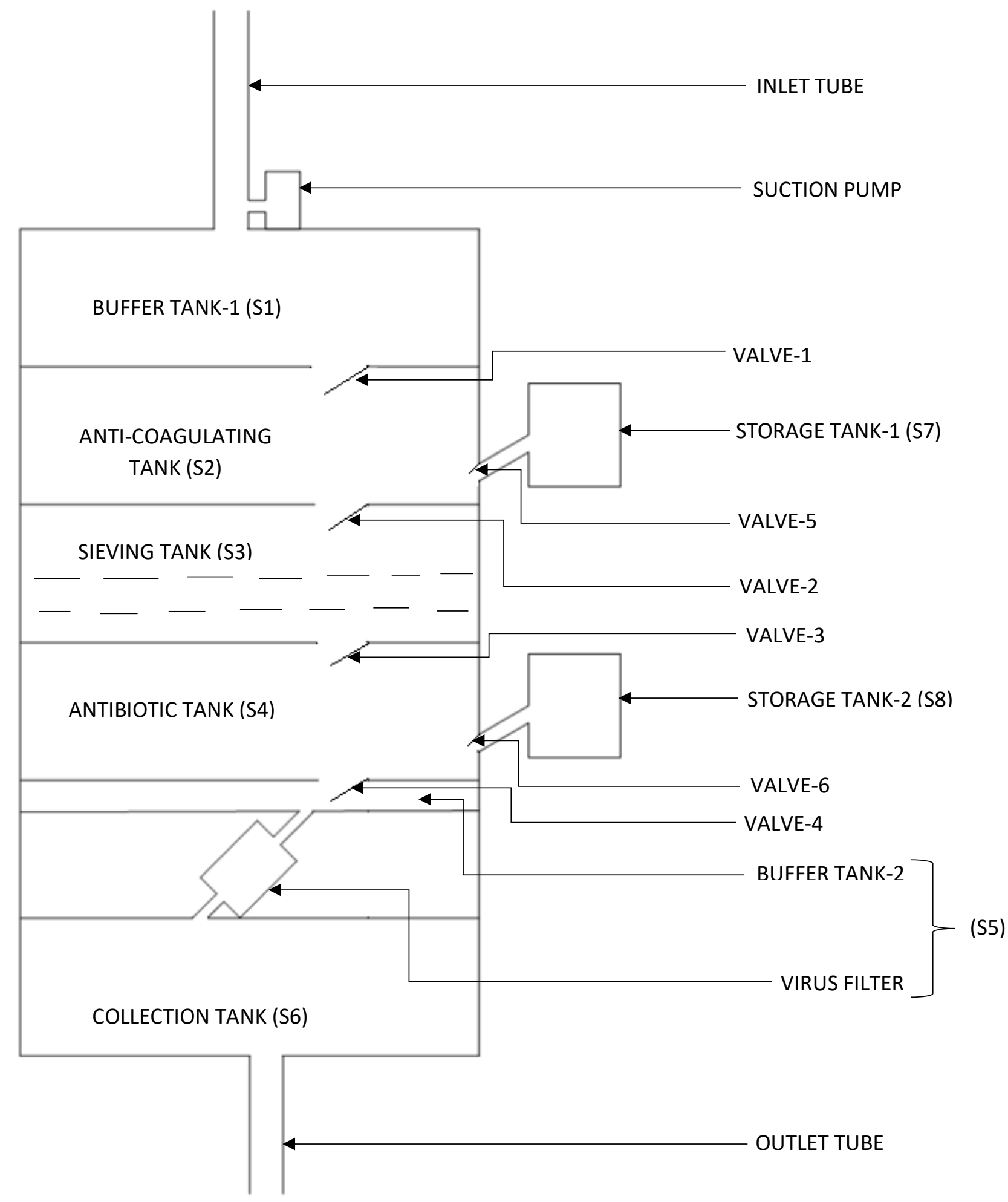

Fig. 1: Schematic representation of the device. 


\section{Working of the Device}

\subsection{General Working}

The device aims to clean and transfuse 2 liters of blood lost in an unsterilized environment. The cleaning process begins with sieving out larger particles and ends with the removal of all kinds of pathogens. To ensure that the blood does not coagulate during the process, the interior of the entire device is lined with an anticoagulant. In addition to this, an anticoagulant tank filled with anticoagulating solution is used to prevent the blood from coagulating. The blood after collection from the inlet tube enters the anticoagulation tank. The blood next moves to the sieving tank whose primary purpose is to let erythrocytes, leukocytes and thrombocytes along with the blood plasma to pass through it and reach the antibiotic tank. Erythrocytes with an average cell size of 8 microns serves as a reference while selecting the pore size of the sieves [3]. In the antibiotic tank, the blood is further mixed with a solution of carbapenems and polyene antifungals, which removes a wide spectrum of bacteria and fungi from the blood [4]. Next, the blood is passed on to the virus filter that is used to remove disease-causing viruses from the blood. This finishes the cleaning process and finally autologous retransfusion is carried out by sending the blood back into the body using an IV tube. In order to ensure continuous retransfusion of cleaned blood back into the body, the blood is purified in batches. To clean and transfuse 2 liters of shed blood, the blood is passed through the device in 5 batches. The response time of the first batch is 60 seconds. Here, response time refers to the time taken to collect, clean and retransfuse the first batch of blood back into the body. To achieve this response time of 60 seconds, a flow rate of blood through the inlet IV tube should be maintained approximately at 0.0067 litres per second.

\subsection{Partwise Working}

This section describes the working of each segment of the device. The status of different tanks at different times has been shown in Table 1.

Table 1: Tank Status.

\begin{tabular}{|c|c|c|c|c|c|c|c|c|}
\hline $\begin{array}{c}\text { Time } \\
\text { (seconds) }\end{array}$ & S1 & S2 & S3 & S4 & S5 & S6 & S7 & S8 \\
\hline 0-8 & $\begin{array}{c}\text { No } \\
\text { function }\end{array}$ & $\begin{array}{l}\text { Fills up blood } \\
\text { with } \\
\text { anticoagulants }\end{array}$ & $\begin{array}{c}\text { No } \\
\text { function }\end{array}$ & No function & No function & No function & $\begin{array}{l}\text { Anticoagu } \\
\text { lant added }\end{array}$ & No function \\
\hline $8-20$ & $\begin{array}{c}\text { Collects } \\
\text { blood }\end{array}$ & $\begin{array}{c}\text { Blood anti- } \\
\text { coagulates }\end{array}$ & $\begin{array}{c}\text { No } \\
\text { function }\end{array}$ & No function & No function & No function & $\begin{array}{c}\text { No } \\
\text { function }\end{array}$ & No function \\
\hline $20-28$ & $\begin{array}{c}\text { Collects } \\
\text { blood }\end{array}$ & Empties blood & $\begin{array}{c}\text { Starts } \\
\text { sieving }\end{array}$ & No function & No function & No function & $\begin{array}{c}\text { No } \\
\text { function }\end{array}$ & No function \\
\hline $28-36$ & $\begin{array}{l}\text { Empties } \\
\text { blood }\end{array}$ & $\begin{array}{l}\text { Fills up blood } \\
\text { with } \\
\text { anticoagulants }\end{array}$ & $\begin{array}{c}\text { Finishes } \\
\text { sieving }\end{array}$ & $\begin{array}{l}\text { Fills up blood } \\
\text { with antibiotics } \\
\text { cocktail }\end{array}$ & No function & No function & $\begin{array}{l}\text { Anticoagu } \\
\text { lant added }\end{array}$ & $\begin{array}{c}\text { Antibiotic } \\
\text { cocktail } \\
\text { added } \\
\end{array}$ \\
\hline $36-48$ & $\begin{array}{l}\text { Collects } \\
\text { blood }\end{array}$ & $\begin{array}{l}\text { Blood anti- } \\
\text { coagulates }\end{array}$ & $\begin{array}{c}\text { No } \\
\text { function }\end{array}$ & $\begin{array}{l}\text { Purification of } \\
\text { blood occurs }\end{array}$ & No function & No function & $\begin{array}{c}\text { No } \\
\text { function }\end{array}$ & No function \\
\hline 48-60 & $\begin{array}{l}\text { Collects } \\
\text { blood }\end{array}$ & Empties blood & $\begin{array}{l}\text { Starts } \\
\text { sieving }\end{array}$ & $\begin{array}{l}\text { Empties blood } \\
\text { into the buffer } \\
\text { tank } 2\end{array}$ & $\begin{array}{l}\text { Removal of } \\
\text { viruses }\end{array}$ & $\begin{array}{l}\text { Starts filling and } \\
\text { emptying into } \\
\text { outlet tube }\end{array}$ & $\begin{array}{c}\text { No } \\
\text { function }\end{array}$ & No function \\
\hline $60-68$ & $\begin{array}{l}\text { Empties } \\
\text { blood }\end{array}$ & $\begin{array}{l}\text { Fills up blood } \\
\text { with } \\
\text { anticoagulants }\end{array}$ & $\begin{array}{c}\text { Finishes } \\
\text { sieving }\end{array}$ & $\begin{array}{l}\text { Fills up blood } \\
\text { with antibiotics }\end{array}$ & $\begin{array}{l}\text { Removal of } \\
\text { viruses }\end{array}$ & $\begin{array}{l}\text { Starts filling and } \\
\text { emptying into } \\
\text { outlet tube }\end{array}$ & $\begin{array}{l}\text { Anticoagu } \\
\text { lant added }\end{array}$ & $\begin{array}{l}\text { Antibiotic } \\
\text { cocktail } \\
\text { added }\end{array}$ \\
\hline 68-80 & $\begin{array}{l}\text { Collects } \\
\text { blood }\end{array}$ & $\begin{array}{l}\text { Blood anti- } \\
\text { coagulates }\end{array}$ & $\begin{array}{c}\text { No } \\
\text { function }\end{array}$ & $\begin{array}{l}\text { Purification of } \\
\text { blood occurs }\end{array}$ & $\begin{array}{l}\text { Removal of } \\
\text { viruses }\end{array}$ & $\begin{array}{l}\text { Starts filling and } \\
\text { emptying into } \\
\text { outlet tube }\end{array}$ & $\begin{array}{c}\text { No } \\
\text { function }\end{array}$ & No function \\
\hline $80-88$ & $\begin{array}{l}\text { Collects } \\
\text { blood }\end{array}$ & Empties blood & $\begin{array}{l}\text { Starts } \\
\text { sieving }\end{array}$ & $\begin{array}{l}\text { Empties blood } \\
\text { into the buffer } \\
\text { tank } 2\end{array}$ & $\begin{array}{l}\text { Removal of } \\
\text { viruses }\end{array}$ & $\begin{array}{l}\text { Starts filling and } \\
\text { emptying into } \\
\text { outlet tube }\end{array}$ & $\begin{array}{c}\text { No } \\
\text { function }\end{array}$ & No function \\
\hline 88-100 & $\begin{array}{l}\text { Empties } \\
\text { blood }\end{array}$ & $\begin{array}{l}\text { Fills up blood } \\
\text { with } \\
\text { anticoagulants }\end{array}$ & $\begin{array}{c}\text { Finishes } \\
\text { sieving }\end{array}$ & $\begin{array}{l}\text { Fills up blood } \\
\text { with antibiotics }\end{array}$ & $\begin{array}{c}\text { Removal of } \\
\text { viruses }\end{array}$ & $\begin{array}{l}\text { Starts filling and } \\
\text { emptying into } \\
\text { outlet tube }\end{array}$ & $\begin{array}{l}\text { Anticoagu } \\
\text { lant added }\end{array}$ & $\begin{array}{l}\text { Antibiotic } \\
\text { cocktail } \\
\text { added }\end{array}$ \\
\hline
\end{tabular}




\subsubsection{Inlet Tube}

The inlet tube is an intravenous tube used in conjunction with a suction pump to gather the blood from near and around the wound.

\subsubsection{Anti-Coagulating Tank}

Once outside the body, blood starts to clot. This is due to the presence of 12 clotting factors present inside the blood. Clotting begins whenever there is a change in the blood pressure or if the blood encounters a rough surface. This is the first issue that needs to addressed while collection of blood by the device. The anti-coagulating tank (S2) has the most important task of preventing the blood from clotting. Anti-coagulant from the storage tank-1 mixes with the incoming blood to prevent clotting from taking place. A small rotor based fan is placed to ensure even mixing of the blood with the anti-coagulating agent.

\subsubsection{Sieving Tank}

A pair of sieves are used to remove all particles greater than 15 microns in size, including common dirt, dust and certain bacteria. The sieves cover the entire cross section of the sieving tank (S3). The sieving tank consists of an inbuilt storage unit where the blood is collected until the entire sieving process of a particular batch of blood is completed

\subsubsection{Antibiotic Tank}

The antibiotic tank (S4) is where the mixing of the antibiotics with the blood takes place. A small rotor based fan is used to evenly mix the blood with the broad-spectrum antibiotics, which have been poured into the tank. The fan is operated at a slow speed to prevent damage to the blood cells.

\subsubsection{Virus Filter}

The bloodstream now free of bacteria still contains its pathogenic counterpart-Viruses. Viruses, although the smallest, are the most potent microorganisms, which can cause a lot of trouble unless they are suitably, treated. Although earlier a challenge, during recent times innovative methods to remove viruses from the blood are gaining momentum. Among the forerunners is an antibody coated filter that actively removes viruses from the bloodstream [5].

\subsubsection{Collection Tank}

After the purification process has been completed, the blood reaches the collection tank where it is stored until it is ready to be taken into the body. The need for the collection tank arises because the rate at which the blood can be transfused back into the body through the outlet tube is slower than the rate at which the blood is purified.

\subsubsection{Outlet Tube}

An intravenous tube delivers the blood drop by drop into the selected vein.

\subsubsection{Storage Tanks}

Two buffer tanks are used in the device. The inlet tube terminates into Buffer tank 1, which acts as an intermediate storage tank that temporarily stores the blood while the blood is anti-coagulated in the anti-coagulating tank (S1). Buffer tank 2 is used between the Antibiotic tank and the virus filtering section. The rate at which the blood is emptied out from the antibiotic tank is not the same as that at which the virus is filtered out of the blood, which creates the requirement for buffer tank 2, which acts a temporary storage facility until the blood can enter the virus filter.

\subsubsection{Actuating Valves}

A set of six valves are used to allow the blood to flow in and out of the respective tanks that are otherwise isolated from one other. A timing circuit is used to coordinate the opening and closing of the valves.

The order in which the valves are actuated are stated in Table 2 where valve opening is denoted by 1 and valve closing is denoted by 0 . 
Table 2: Valve Status.

\begin{tabular}{|c|c|c|c|c|c|c|}
\hline Time(seconds) & V1 & V2 & V3 & V4 & V5 & V6 \\
\hline $\mathbf{0 - 8}$ & 1 & 0 & 0 & 0 & 1 & 0 \\
\hline $\mathbf{8 - 2 0}$ & 0 & 0 & 0 & 0 & 0 & 0 \\
\hline $\mathbf{2 0 - 2 8}$ & 0 & 1 & 0 & 0 & 0 & 0 \\
\hline $\mathbf{2 8 - 3 6}$ & 1 & 0 & 1 & 0 & 1 & 1 \\
\hline $\mathbf{3 6 - 4 8}$ & 0 & 0 & 0 & 0 & 0 & 0 \\
\hline $\mathbf{4 8 - 6 0}$ & 0 & 1 & 0 & 1 & 0 & 0 \\
\hline $\mathbf{6 0 - 6 8}$ & 1 & 0 & 1 & 0 & 1 & 1 \\
\hline $\mathbf{6 8 - 8 0}$ & 0 & 0 & 0 & 0 & 0 & 0 \\
\hline $\mathbf{8 0 - 8 8}$ & 0 & 1 & 0 & 1 & 0 & 0 \\
\hline $\mathbf{8 8 - 1 0 0}$ & 1 & 0 & 1 & 0 & 1 & 1 \\
\hline
\end{tabular}

\section{Discussion}

The device aims to start autologous blood transfusion with a response time of 60 seconds and goes on to clean the entire volume of the blood lost (upto 2 liters). The proposed device removes the foreign particles encountered by the blood in a sequential manner. Thus, autologous transfusion can be safely carried out in an unsterilized environment. In addition, this device is portable and can be used as a supplement during emergencies until proper medical care can be provide.

Soldiers affected in war, victims of a natural calamity may experience blood loss and there may not be immediate and sufficient allogeneic blood available for transfusion. The proposed device can play a vital role in providing immediate relief and can even save the life of the affected individual(s).

\section{Future Work}

This section discusses some additional fine-tuning that needs to be carried out in order to perfect the system. This includes deciding what material the respective tanks will be made of. An optimum shape for each tank will be selected after which the exact dimensions of every section will be finalized. The wiring harness will be routed and laid and the power consumed will be calculated. After finalizing every aspect of the proposed device, it will be timed and its response time will be accurately noted.

\section{Acknowledgements}

The authors would primarily like to acknowledge Mrs. Monita Dash for her guidance and knowledge throughout the course of writing this paper.

\section{References}

[1] A. Walunj, A. Babb, and R. Sharpe, "Autologous blood transfusion," Continuing Education in Anaesthesia, Critical Care and Pain, vol. 6, no. 5, pp. 192-196, 2006.

[2] A. Venosa, (September 3, 2015), Breaking Point: How Much Blood Can The Human Body Lose?. [Online]. Available: http://www.medicaldaily.com/breaking-point-how-much-blood-can-human-body-lose-350792

[3] M. L. Turgeon, Clinical hematology: theory and procedures. Lippincott Williams \& Wilkins, 2005, p. 100.

[4] K. M. Papp-Wallace, A. Endimiani, M. A. Taracila, and R. A. Bonomo, "Carbapenems: past, present, and future," Antimicrobial agents and chemotherapy, vol. 55, no. 11, pp. 4943-4960, 2011.

[5] J. Joyce, (February 12, 2015), A Publication Describing the First Treatment of Ebola with the Aethlon Hemopurifier®. [Online]. Available: https://www.aethlonmedical.com/news-media/pressreleases/detail/271/aethlon-medical-inc---a-publication-describing-the-first 